\title{
THE CONNECTION BETWEEN INFLATION UNCERTAINTY AND INFLATION: HIGH OR HIGHER INFLATION RATE EVIDENCE FROM THE EGYPTIAN ECONOMY (2011-2018)
}

\author{
Dr. Mostafa H. Elsayed \\ Economic Department, HIMIT, Kafr El Sheikh. \\ DOI: 10.46609/IJSSER.2020.v05i02.014 URL: https://doi.org/10.46609/IJSSER.2020.v05i02.014
}

\begin{abstract}
Uncertainty is the situation in which something is not well known, so inflation uncertainty can be simply defined as proportional deviation of inflation rate from its expected rate; that is the something matter in inflation uncertainty is the difference between the mean rate of inflation rate and its current rate regardless how high it is. After $25^{\text {th }}$ Jan revolution; inflation has been one of the most serious problems that face Egyptian economy, so the present study examines the relationship between inflation uncertainty and inflation in Egyptian economy from 2011M1 to 2018M12 using two-step procedure. At the first step, a monthly data GARCH model of inflation is estimated to obtain the conditional variance which in turn use as approximation of the inflation uncertainty. Then, the Granger causality tests between inflation series and the obtained conditional variance (inflation uncertainty) series are implemented. Empirical results of the study provided an evidence for the mutual interdependence between the two variables, that is, higher inflation rate above its mean rate will lead to high inflation uncertainty and vice versa, and in the same time stable high inflation rate leads to less sensitiveness of inflation uncertainty to increase in inflation rate. In some context this result modifies both Friedman-Ball hypothesis and Cukierman and Meltzer hypothesis that higher (not high) inflation rate affect and affected by inflation uncertainty.
\end{abstract}

Keywords: inflation, inflation uncertainty, Friedman-Ball hypothesis, Cukierman and Meltzer Hypothesis

\section{INTRODUCTION}

No doubt that high level inflation rates are harmful for all economies, but it's more harmful for developing countries because of the existence of poverty, unemployment and inefficient financial 


\section{International Journal of Social Science and Economic Research}

ISSN: $2455-8834$

Volume: 05, Issue: 02 "February 2020"

sector; which make the economic structure of developing economies is dissimilar than the developed ones. So, someone could say that inflation makes monetary policy more confusing in developing nations. Consequently many aspects of inflation have been extensively paid the attention of the economic thought such as the relationship between inflation and its uncertainty because of inflation uncertainty represents one of the costs of inflation. In other words, we should keep in mind the fact that expected inflation has a vital role to play in an economic decision, so; economists need to focus on the connection between inflation and inflation uncertainty which often refers to unpredictable volatility (see, Barnett et al (2018), Rosi et al (2016)).

Inflation uncertainty may affect economy through two ways:

First the ex-ante effect; at which inflation uncertainty causes firms and households to make economic decisions differ from the ones they would make in certainty, so it affects the decisions related to the future expected inflation. So, the ex-ante effect moves through three channels:

- First, inflation uncertainty affects financial markets by increasing long-term interest rates. That is; if inflation is uncertain, the real return on long term debt will be more risky. As a result, investors will require higher returns, which imply higher long-term real interest rates.

- Second, inflation uncertainty leads to uncertainty about other economic variables (such as exchange rate, wages etc). In other words; when the payments in a contract are not indexed to inflation, inflation uncertainty causes the real value of future payments to be uncertain.

- Finally, inflation uncertainty encourages firms to spend resources avoiding the associated risks. For example, when inflation uncertainty is high firms will spend more resources to improve their forecast about inflation, besides; some organizations will try to hedge against unexpected inflation using specialized financial derivatives. But both forecasting and hedging activities imply that resources are diverted from other more productive business purposes.

The second is ex post effect; at which effects takes place after the decisions have been made, these effects occur when inflation differs from what had been expected. For instance; when inflation is higher than forecast, the real value of nominal payments is lower than expected, implies a transfer of wealth from the lender to the borrower, and many economic agent will hurt by an unexpected increase in inflation. 


\section{International Journal of Social Science and Economic Research}

ISSN: $2455-8834$

Volume: 05, Issue: 02 "February 2020"

However it is broadly recognized that high inflation is harmful for economic activities, there are different points of view about the direction of relation between inflation and its uncertainty in economic literature. Thus, the purpose of the study is to examine the connection between inflation and inflation uncertainty in Egypt over the period 2011M1-2018M12. Following the studies in this topic such as Grier and Perry (1998) and Nas and Perry (2000), two-step methodology has been used where in the first step is the Generalized Autoregressive Conditional Heteroskedasticity (GARCH) models are estimated to generate an approximation measure of inflation uncertainty and in the second step Granger causality test has been carried out. After the economic reform in 1990-1991, Egypt has considered Inflation Targeting (IT) as a monetary policy main objective after 1991. So, the results of this study have some implications for Egyptian Inflation Targeting Policy as well as the literature which concentrating on the association between inflation and inflation uncertainly particularly in developing countries.

The paper proceeds as following plan. Section 2 tries to preview the different hypothesis which connecting inflation and inflation uncertainty. Section 3 previews the related empirical studies and its results. Section 4 presents data and the methodological issues. Section 5 prevents empirical results, conclusion and offering the some policy implications.

\section{LITERATURE REVIEW}

Inflation is defined as a continuous increase in the overall price level, while inflation uncertainty denotes to the situation at which future inflation are unpredictable and most people do not know whether inflation level will rise or fall in the future. In other words future inflation rate is highly unpredictable to the public.

Uncertainty about Inflation is both a cause and a result of inflation, its well- known that without uncertainty economic units could plan better for the future, that is, as (Rizvi and Naqvi, 2008, p. 2) noted, uncertainty about inflation is considered one of the main costs of inflation since it not only misleads the decisions about saving and investment due to lower certainty of the real value of future payments, but also it distorts the efficiency of resource allocation so the level of real activity. So there is a question about how inflation uncertainty interdepends with the economy?

(Golob, 1994) stated that, whenever anticipated inflation is an element in economic decision making, inflation uncertainty is also likely to be a factor. But, the connection between inflation and inflation uncertainty is doubtful and there are different points of view about the direction of their relation in economic literature.

Friedman (1977) and Ball (1990) provide the so called Friedman - Ball hypothesis which stated that inflation causes inflation uncertainty. While Cukierman and Mezler (1986), and Perry and 
Grier (1998) provide evidence in adverse direction, and support that the causality running from inflation uncertainty to inflation. At the same time, Pourgerami and Maskus (1987) and Ungar and Zilberfarb (1993) as well as Holland (1995) confirmed that there is a negative association between inflation and inflation uncertainty. Accordingly, the association between inflation and inflation uncertainty has received considerable attention in economic literature, and divided into two groups of hypothesis; positive association hypotheses and the negative association hypotheses. These are some of the possible channels by which the connection between inflation and inflation uncertainty could be illustrated. Consequently, the result of this study will determine which of the above hypothesis holds true for the case ofEgypt.

\subsection{The positive association hypotheses:}

\subsubsection{Friedman-Ball Hypothesis}

The seminal work of Okun (1971) argued that inflation is positively connected with its standard deviation by using data of 17 OECD countries for the period from 1951 to 1968.

According to Okun there is a positive association between inflation and the variability of inflation the case at which monetary policy becomes more unpredictable in high inflation periods. So, Friedman (1977) outlined an argument about how an increase in inflation rate raises inflation variability in the case of unpredictable monetary policy that go together with inflationary periods. According to Friedman, high inflation rate makes a political pressure to reduce it; however policymakers may be reluctant to reduce inflation because they don't want the recessionary effects of contractionary monetary policy. Hence, the future monetary policy will be difficult to predict in high inflation periods, in other words, higher inflation results in larger uncertainty about future inflation.

In other words, Friedman (1977) stated that an increase in inflation rate may make an unpredictable policy response by monetary authorities and therefore, lead to more uncertainty about the future inflation rate. So his argument could be illustrated in this way:

Figure 1: Illustration of Friedman-Ball Hypothesis
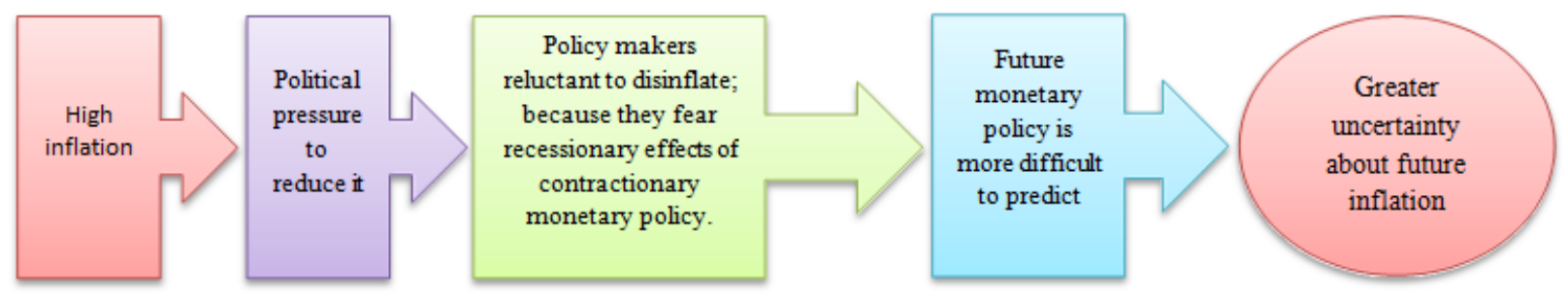


\section{International Journal of Social Science and Economic Research}

ISSN: $2455-8834$

Volume: 05, Issue: 02 "February 2020"

In the related literature, Ball (1992) built an economic model to support Friedman's hypothesis. Ball's model takes up two policymakers; one accepts to bear recession to reduce inflation, and the other is not. For the low levels of inflation, both of them will try to keep inflation rate low. However, for the high inflation rates, only the anti-inflation one will accept to bear the recession as an economic cost of disinflation. Consequently, during the periods of high inflation, the community will be uncertain about the future monetary policy because they do not know whether the policymakers are anti-inflation or not. So the contribution of Ball's Model and Friedman's argument is called Friedman-Ball Hypothesis, which stated that there is a positive relation from inflation to inflation uncertainty.

\subsubsection{Cukierman and Meltzer Hypothesis:}

The opposite connection stated that inflation variability will lead to higher inflation, that there is a positive relation from inflation uncertinity to inflation. Cukierman and Meltzer (1986) run the causality test from inflation uncertainty to inflation; assuming that policymakers have two inconsistent targets over time. The first target is that, monetary authority prefer to expanding output by making monetary shocks; however the second target is to keep inflation at low levels. Consequently, the monetary policy is then assumed to be stochastic due to nonspecific monetary control mechanism. Furthermore, inefficient policymakers may not able to use the most appropriate monetary instrument available when they determine the accuracy of monetary control. Particularly, during periods of increased uncertainty, monetary policy may be discretionary because of the increased incentive to stimulate output growth by making monetary shocks. Thus, inflation uncertainty may lead to higher rates of money growth and then leads to inflation. The argument that higher inflation uncertainty will lead to high inflation rate is called Cukierman and Meltzer Hypothesis. The hypothesis that could be illustrated in this way.

Figure 2: Illustration of Cukierman and Meltzer Hypothesis:
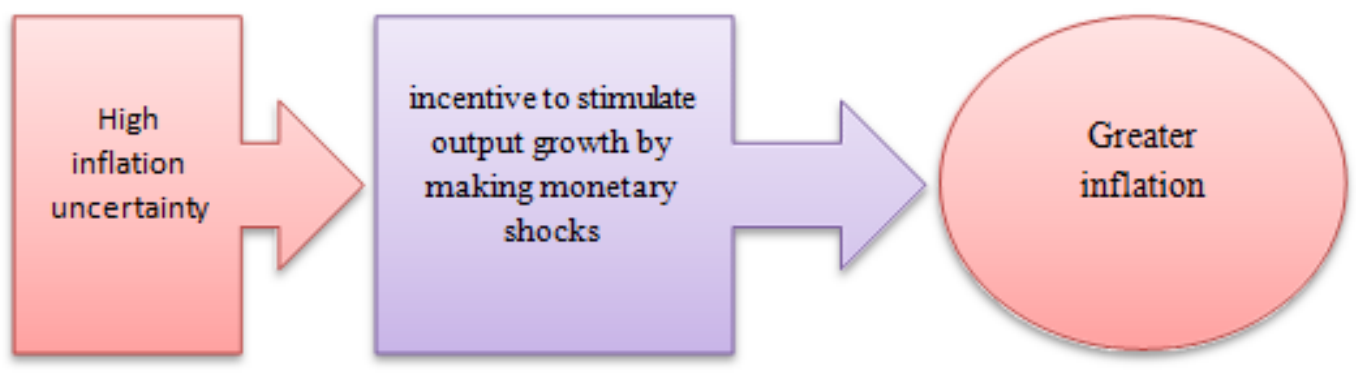

In brief words, Cukierman and Meltzer stated that the causality between inflation and inflation uncertinity runs from inflation uncertainty to inflation. That is, the more the inflation uncertainty, the more the incentive for policymakers to create inflation shock to achieve sustainable 
economic growth.

\subsection{The negative association hypotheses:}

\subsubsection{Pourgerami and Maskus Hypothesis:}

Against to Friedman-Ball Hypothesis, another contribution concerning the relationship between inflation and inflation uncertainty is stated by Pourgerami and Maskus (1987). They show that there is a negative association between inflation and inflation uncertainty, that is the more the inflation is; the less the inflation uncertainty will be.

They stated that higher inflation stimulates economic agents to invest in inflation prediction process to make accurate predictions about inflation, which reduces their prediction error. Therefore, in the higher inflation periods, economic units may forecast inflation better and decrease the inflation uncertainty. In other words, they assumed a negative relationship between inflation and inflation uncertainty. Because when inflation rates increases economic units use more resources in forecasting inflation because they have to take many decisions about investment, consumption, production etc. accordingly inflation can be anticipated and this will decrease the inflation uncertainty.

The described mechanism of the relation from higher inflation rate to lower inflation uncertainty is called "Pourgerami and Maskus Hypothesis".

In a related context, Ungar and Zilberfarb (1993) developed this argument through the theoretical modeling of the hypothesis that economic units use more resource in inflation forecasting process in the periods of high inflation rates. Consequently, they supported that inflation itself generates a dynamic triggering more anticipated level of prices and decreasing the inflation uncertainty. So, the mechanism stated by Pourgerami and Maskus (1987) as well as by Ungar and Zilberfarb (1993). Could be illustrated as follows:

Figure 3: Illustration of Pourgerami and Maskus Hypothesis

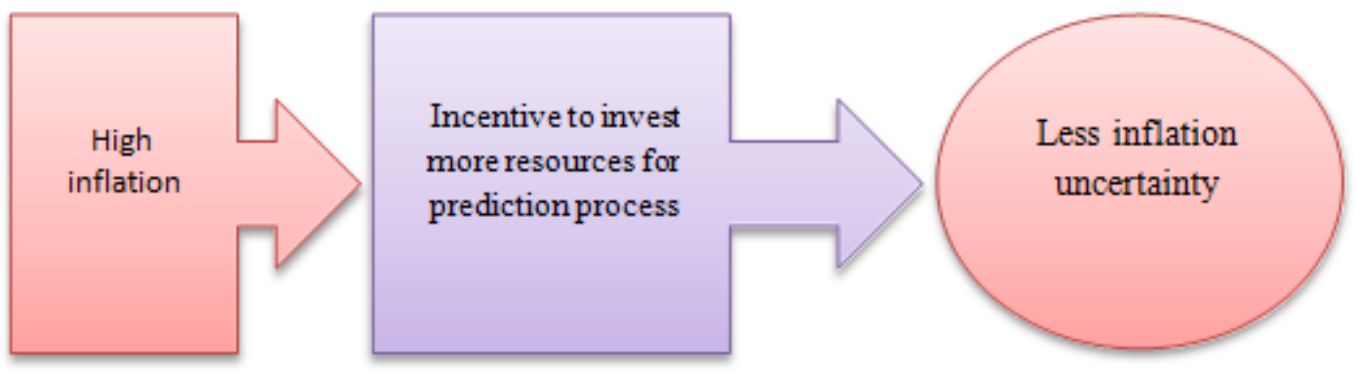




\subsubsection{Holland stabilizing Fed Hypothesis:}

Holland (1995) stated that higher inflation variability will lead to lower levels of inflation due to stabilization motives of policymakers. So, he contradicted Cukierman and Meltzer (1986) hypothesis and argued that more inflation uncertainty may lead to a lower inflation rate, if the monetary authority attempts to minimize the welfare losses caused by inflation uncertainty.

Holland argued the so-called "stabilizing Fed hypothesis", that is; inflation increases inflation uncertainty in US economy and that higher inflation uncertainty result in lower inflation rates. Holland assumed that stabilization propensity of monetary authority increases in high inflation period in order to decrease the cost of inflation uncertainty for the economy. Consequently, Holland's argument depends on the policymaker strong stabilization motive. By the rejecting of Cukierman-Meltzer's assumption, Holland stated that central banks usually prefer to decrease money supply growth rate in order to reduce the negative effect of inflation uncertainty on economic welfare arising from higher inflation levels. This is true if and only if the policymakers either have stabling motives or they governed by electionary commitment that requires price level stability.

The channel behind "Holland Hypothesis" may be illustrated as:

\section{Figure 3: Illustration of Holland Hypothesis}

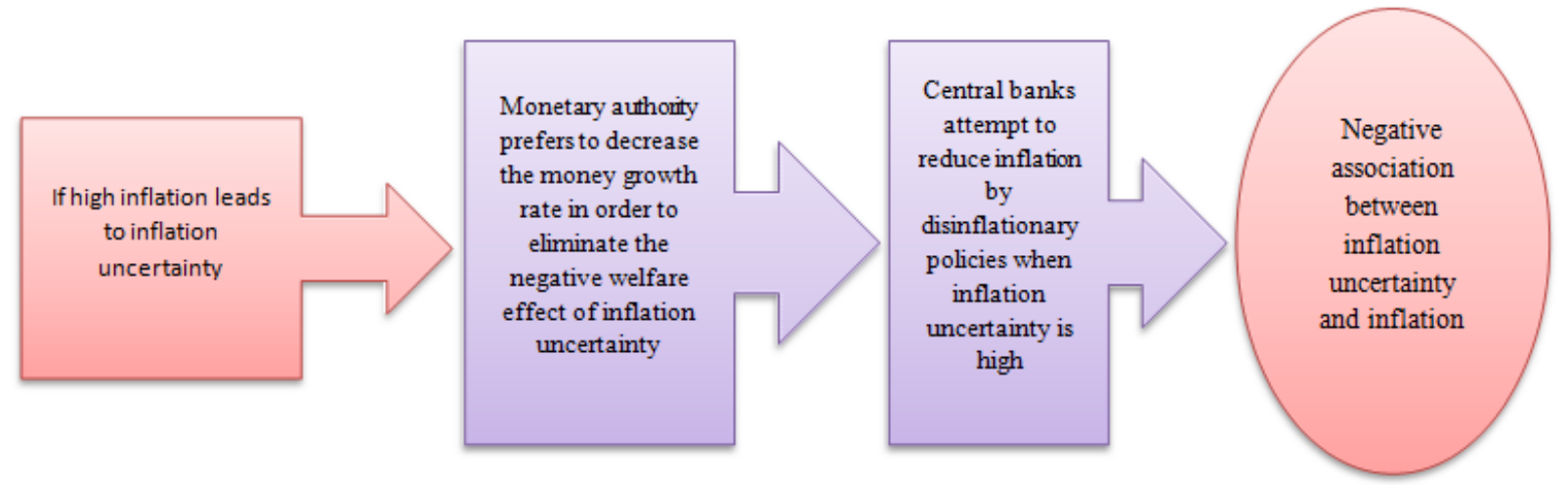

So, according to the conceptual base, the connection between inflation and inflation uncertainty could be summarized in the following table: 
Table 1: How inflation and inflation uncertainty are related:

\begin{tabular}{|l|l|l|}
\hline Causality & Positive association & Negative association \\
\hline $\begin{array}{l}\text { Inflation causes inflation } \\
\text { uncertainty }\end{array}$ & $\begin{array}{l}\text { Friedman and Ball } \\
\text { hypothesis }\end{array}$ & $\begin{array}{l}\text { Pourgerami and Maskus } \\
\text { hypothesis }\end{array}$ \\
\hline $\begin{array}{l}\text { Inflation uncertainty } \\
\text { causes inflation }\end{array}$ & $\begin{array}{l}\text { Cukierman and Meltzer } \\
\text { hypothesis }\end{array}$ & Holland hypothesis \\
\hline
\end{tabular}

\section{IMPERIAL REVIEW}

The empirical studies examined the interdependence between inflation and inflation uncertainty generally focused on HDCs. In these studies, Generalized Autoregressive Conditional Heteroskedasticity (GARCH) specifications are widespread; this is because $(\mathrm{GARCH})$ estimates the conditional variance, so it can serve as a proxy for inflation uncertainty. According to the survey of Davis and Kanago (2000), studies focusing on developed countries mostly supported Friedman-Ball Hypothesis more than the hypothesis of Cukierman-Meltzer, at the same time there is a little evidence to the hypothesis of Pourgerami and Maskus and Holland.

Table 2: Some empirical studies examined the interdependence between inflation and inflation uncertainty

\begin{tabular}{|l|l|l|l|l|l|}
\hline & \multicolumn{5}{|l|}{ High developed countries (HDCs) studies } \\
\hline & Author & Country & Data & Tested by & $\begin{array}{l}\text { The } \\
\text { results } \\
\text { supported }^{*}\end{array}$ \\
\hline 2 & $\begin{array}{l}\text { Logue, Willet } \\
(1976)\end{array}$ & $\begin{array}{l}41 \\
\text { Countries }\end{array}$ & $\begin{array}{l}1948-1970 \\
\text { (annual) }\end{array}$ & $\begin{array}{l}\text { Inflation's mean and } \\
\text { standard deviation }\end{array}$ & FB \\
\hline 1 & $\begin{array}{l}\text { Evans, Wachtel } \\
(1993)\end{array}$ & USA & $\begin{array}{l}1955-1991 \\
\text { (quarterly) }\end{array}$ & Markov & CM \\
\hline 3 & $\begin{array}{l}\text { Grier, Perry } \\
(1998)\end{array}$ & G7 & $\begin{array}{l}1948-1993 \\
\text { (monthly) }\end{array}$ & GARCH & $\begin{array}{l}\text { FB } \\
\text { CM }\end{array}$ \\
\hline
\end{tabular}


International Journal of Social Science and Economic Research

ISSN: 2455-8834

Volume: 05, Issue: 02 "February 2020"

\begin{tabular}{|c|c|c|c|c|c|}
\hline 4 & $\begin{array}{l}\text { Fountas and } \\
\text { Karanasos } \\
(2000)\end{array}$ & USA & $\begin{array}{l}\text { 1960-1999 } \\
\text { (monthly) }\end{array}$ & GARCH & $\begin{array}{l}\mathrm{FB} \\
\mathrm{CM}\end{array}$ \\
\hline 5 & Hwang (2001) & USA & $\begin{array}{l}\text { 1947-1992 } \\
\text { (monthly), } \\
\text { 1926-1940 } \\
\text { (monthly) }\end{array}$ & $\begin{array}{l}\text { ARFIMA } \\
\text { GARCH } \\
\text { GARCH-M }\end{array}$ & $\begin{array}{l}\mathrm{PM} \\
\mathrm{CM}\end{array}$ \\
\hline 6 & Fountas (2001) & England & $\begin{array}{l}\text { 1885-1998 } \\
\text { (annual) }\end{array}$ & GARCH & FB \\
\hline 7 & $\begin{array}{l}\text { Bhar and } \\
\text { Hamori (2001) }\end{array}$ & $\begin{array}{l}\text { G7 } \\
\text { countries }\end{array}$ & $\begin{array}{l}\text { 1961-1999 } \\
\text { (Quarterly) }\end{array}$ & $\begin{array}{l}\text { Markov Switching } \\
\text { Heteroskedasticity } \\
\text { model }\end{array}$ & FB \\
\hline 8 & $\begin{array}{l}\text { Kontonikas } \\
(2004)\end{array}$ & England & $\begin{array}{l}\text { 1972-2002 } \\
\text { (annual) }\end{array}$ & GARCH-M & FB \\
\hline 9 & $\begin{array}{l}\text { Fountas et al } \\
(2004)\end{array}$ & $\begin{array}{l}\text { Germany, } \\
\text { France, } \\
\text { Spain, } \\
\text { England, } \\
\text { Netherlands, } \\
\text { Italia }\end{array}$ & $\begin{array}{l}\text { 1960-1999 } \\
\text { (monthly) }\end{array}$ & EGARCH & $\begin{array}{l}\text { FB } \\
\mathrm{H}\end{array}$ \\
\hline 10 & $\begin{array}{l}\text { Bredin and } \\
\text { Fountas (2006) }\end{array}$ & $\begin{array}{l}\text { Germany, } \\
\text { Italy, UK, } \\
\text { and Holland }\end{array}$ & $\begin{array}{l}\text { 1968-2005 } \\
\text { (Quarterly) }\end{array}$ & $\begin{array}{l}\text { Markov Switching } \\
\text { Heteroskedasticity } \\
\text { model }\end{array}$ & FB \\
\hline 11 & Wilson (2006) & Japan & $\begin{array}{l}\text { 1957-2002 } \\
\text { (Annual) }\end{array}$ & EGARCH-M & $\mathrm{CM}$ \\
\hline 12 & $\begin{array}{l}\text { Conrad, } \\
\text { Karanasos } \\
(2005)\end{array}$ & $\begin{array}{l}\text { USA, Japan, } \\
\text { England }\end{array}$ & $\begin{array}{l}\text { 1962-2001 } \\
\text { (monthly) }\end{array}$ & $\begin{array}{l}\text { ARFIMA } \\
\text { FIGARCH }\end{array}$ & $\begin{array}{l}\mathrm{FB} \\
\mathrm{CM}\end{array}$ \\
\hline
\end{tabular}


International Journal of Social Science and Economic Research

ISSN: $2455-8834$

Volume: 05, Issue: 02 "February 2020"

\begin{tabular}{|c|c|c|c|c|c|}
\hline 13 & $\begin{array}{l}\text { Fountas and } \\
\text { Karanasos } \\
(2007)\end{array}$ & for the $\mathrm{G} 7$ & $\begin{array}{l}\text { 1957-2000 } \\
\text { (monthly) }\end{array}$ & GARCH & FB \\
\hline 14 & $\begin{array}{l}\text { Karanasos, } \\
\text { Schurer (2008) }\end{array}$ & $\begin{array}{l}\text { Germany, } \\
\text { Netherlands } \\
\text { Sweden }\end{array}$ & $\begin{array}{l}\text { 1962-2004 } \\
\text { (monthly) }\end{array}$ & PARCH & $\begin{array}{l}\mathrm{CM} \\
\mathrm{H} \\
\mathrm{FB}\end{array}$ \\
\hline 15 & $\begin{array}{l}\text { Coporale } \text { et al } \\
\text { (2009) }\end{array}$ & Euro area & $\begin{array}{l}\text { 1980-2009 } \\
\text { (monthly) }\end{array}$ & AR-GARCH & FB \\
\hline 16 & $\begin{array}{l}\text { Bhar, Mallik } \\
(2010)\end{array}$ & USA & $\begin{array}{l}\text { 1957-2007 } \\
\text { (monthly) }\end{array}$ & EGARCH-M & $\begin{array}{l}\mathrm{FB} \\
\mathrm{CM}\end{array}$ \\
\hline 17 & Fountas (2010) & $\begin{array}{l}22 \text { industrial } \\
\text { countries }\end{array}$ & $\begin{array}{l}\text { annual data } \\
\text { over one } \\
\text { century }\end{array}$ & GARCH-M & $\mathrm{CM}$ \\
\hline 18 & $\begin{array}{l}\text { Neanidis and } \\
\text { Sava (2011) }\end{array}$ & $\begin{array}{l}\text { EU } \\
\text { members }\end{array}$ & $\begin{array}{l}\text { 2002-2011 } \\
\text { (monthly) }\end{array}$ & GARCH-M & $\mathrm{CM}$ \\
\hline & \multicolumn{5}{|c|}{ Less developed countries (LDCs) studies } \\
\hline & Author & Country & Data & Tested by & $\begin{array}{l}\text { The } \\
\text { results } \\
\text { supported* }^{*}\end{array}$ \\
\hline 1 & Yamak (1996) & Turkey & $\begin{array}{l}\text { 1949-1992 } \\
\text { (annual) }\end{array}$ & $\begin{array}{l}\text { Two different } \\
\text { methods was used } \\
\text { as ARCH types }\end{array}$ & FB \\
\hline 2 & $\begin{array}{l}\text { Nas and Perry } \\
(2000)\end{array}$ & Turkey & $\begin{array}{l}\text { 1960-1998 } \\
\text { (monthly) }\end{array}$ & GARCH & $\begin{array}{l}\mathrm{FB} \\
\mathrm{CM}\end{array}$ \\
\hline 3 & $\begin{array}{l}\text { Berument et al } \\
(2001)\end{array}$ & Turkey & $\begin{array}{l}\text { 1986-2000 } \\
\text { (monthly) }\end{array}$ & EGARCH & $\mathrm{CM}$ \\
\hline 4 & Telatar (2003) & Turkey & $\begin{array}{l}\text { 1987-2001 } \\
\text { (monthly) }\end{array}$ & $\mathrm{ARCH}$ & FB \\
\hline
\end{tabular}


International Journal of Social Science and Economic Research

ISSN: 2455-8834

Volume: 05, Issue: 02 "February 2020"

\begin{tabular}{|c|c|c|c|c|c|}
\hline 5 & $\begin{array}{l}\text { Chan and Xie } \\
\text { (2003) }\end{array}$ & Taiwan & $\begin{array}{l}\text { 1980-2002 } \\
\text { (monthly) }\end{array}$ & $\begin{array}{l}\text { Hamilton's } \\
\text { flexible non-linear } \\
\text { regression model }\end{array}$ & FB \\
\hline 6 & $\begin{array}{l}\text { Erdoğan, } \\
\text { Bozkurt (2004) }\end{array}$ & Turkey & $\begin{array}{l}\text { 1983-2003 } \\
\text { (monthly) }\end{array}$ & $\begin{array}{l}\text { ARCH GARCH } \\
\text { TARCH }\end{array}$ & FB \\
\hline 7 & $\begin{array}{l}\text { Ozer, } \\
\text { Turkyılmaz } \\
(2005)\end{array}$ & Turkey & $\begin{array}{l}\text { 1990-2004 } \\
\text { (monthly) }\end{array}$ & EGARCH & FB \\
\hline 8 & $\begin{array}{l}\text { Grier and Grier } \\
(2006)\end{array}$ & Mexico & $\begin{array}{l}\text { 1972-2001 } \\
\text { (annual) }\end{array}$ & GARCH-M & FB \\
\hline 9 & $\begin{array}{l}\text { Thornton } \\
\text { (2006) }\end{array}$ & India & $\begin{array}{l}\text { 1957-2005 } \\
\text { (Monthly) }\end{array}$ & GARCH & FB \\
\hline 10 & $\begin{array}{l}\text { Thornton } \\
\text { (2007) }\end{array}$ & $\begin{array}{l}12 \\
\text { Countries in } \\
\text { emerging } \\
\text { markets }\end{array}$ & $\begin{array}{l}\text { Different } \\
\text { periods for } \\
\text { each } \\
\text { countries }\end{array}$ & GARCH & FB \\
\hline 11 & $\begin{array}{l}\text { Ajevskis } \\
(2007)\end{array}$ & Latvia & $\begin{array}{l}\text { 1994-2007 } \\
\text { (monthly) }\end{array}$ & GARCH-M & $\begin{array}{l}\mathrm{FB} \\
\mathrm{CM}\end{array}$ \\
\hline 12 & Erkam (2008) & Turkey & $\begin{array}{l}\text { 1982-2008 } \\
\text { (monthly) }\end{array}$ & $\begin{array}{l}\text { ARCH GARCH and } \\
\text { PARCH }\end{array}$ & $\begin{array}{l}\mathrm{FB} \\
\mathrm{CM}\end{array}$ \\
\hline 13 & $\begin{array}{l}\text { Ozdemir, } \\
\text { Fisunoğlu } \\
(2008)\end{array}$ & $\begin{array}{l}\text { Turkey, } \\
\text { Jordan, } \\
\text { Philippines }\end{array}$ & $\begin{array}{l}\text { 1987-2003 } \\
\text { (monthly) }\end{array}$ & ARFIMA GARCH & $\begin{array}{l}\mathrm{FB} \\
\mathrm{CM}\end{array}$ \\
\hline 14 & Omay (2008) & Turkey & $\begin{array}{l}\text { 1986-2007 } \\
\text { - three } \\
\text { different } \\
\text { periods }\end{array}$ & GARCH & PM \\
\hline 15 & $\begin{array}{l}\text { Thornton } \\
\text { (2008) }\end{array}$ & Argentine & $\begin{array}{l}\text { 1810-2005 } \\
\text { (annual) }\end{array}$ & GARCH & FB \\
\hline 16 & $\begin{array}{l}\text { Rizvi and } \\
\text { Naqvi (2008) }\end{array}$ & Pakistan & $\begin{array}{l}\text { 1976-2008 } \\
\text { (monthly) }\end{array}$ & $\begin{array}{l}\text { T-GARCH and } \\
\text { EGARCH }\end{array}$ & FB \\
\hline
\end{tabular}


International Journal of Social Science and Economic Research

ISSN: $2455-8834$

Volume: 05, Issue: 02 "February 2020"

\begin{tabular}{|c|c|c|c|c|c|}
\hline 17 & Moradi (2008) & Iran & $\begin{array}{l}\text { 1959-2008 } \\
\text { (monthly) }\end{array}$ & $\begin{array}{ll}\text { GARCH } & \text { and } \\
\text { TGARCH } & \end{array}$ & FB \\
\hline 18 & $\begin{array}{l}\text { Korap, } \\
\text { Saatcioğlu } \\
(2009)\end{array}$ & Turkey & $\begin{array}{l}\text { 1987-2008 } \\
\text { (monthly) }\end{array}$ & EGARCH & FB \\
\hline 19 & $\begin{array}{l}\text { Rizvi and } \\
\text { Naqvi (2009) }\end{array}$ & $\begin{array}{l}\text { China, } \\
\text { Hong Kong, } \\
\text { India, } \\
\text { Malaysia, } \\
\text { Pakistan, } \\
\text { Philippines, } \\
\text { Singapore, } \\
\text { South } \\
\text { Korea, } \\
\text { Indonesia } \\
\text { and } \\
\text { Thailand. }\end{array}$ & $\begin{array}{l}\text { 1987-2008 } \\
\text { (Quarterly) }\end{array}$ & GARCH & $\begin{array}{l}\text { FB } \\
\mathrm{CM}\end{array}$ \\
\hline 20 & $\begin{array}{l}\text { Turky1lmaz, } \\
\text { Ozer (2010) }\end{array}$ & Turkey & $\begin{array}{l}\text { 1997-2008 } \\
\text { (monthly) }\end{array}$ & MGARCH & $\begin{array}{l}\text { FB } \\
\mathrm{CM}\end{array}$ \\
\hline 21 & $\begin{array}{l}\text { Jiranyakul, } \\
\text { Opiela (2010) }\end{array}$ & $\begin{array}{l}\text { Indonesia, } \\
\text { Malaysia, } \\
\text { Philippines, } \\
\text { Singapore, } \\
\text { Thailand }\end{array}$ & $\begin{array}{l}\text { 1970-2007 } \\
\text { (annual) }\end{array}$ & EGARCH & $\begin{array}{l}\mathrm{FB} \\
\mathrm{CM}\end{array}$ \\
\hline 22 & $\begin{array}{l}\text { Keskek and } \\
\text { Orhan (2010) }\end{array}$ & Turkey & $\begin{array}{l}\text { 1984-2005 } \\
\text { (monthly) }\end{array}$ & GARCH-M & FB \\
\hline 23 & $\begin{array}{l}\text { Telatar and } \\
\text { Telatar (2003) }\end{array}$ & Turkey & $\begin{array}{l}\text { 1995-2000 } \\
\text { (monthly) }\end{array}$ & $\begin{array}{l}\text { Markov Switching } \\
\text { Heteroskedasticity } \\
\text { model }\end{array}$ & FB \\
\hline 24 & $\begin{array}{l}\text { Nazar et al } \\
(2010)\end{array}$ & Iran & $\begin{array}{l}\text { 1959-2009 } \\
\text { (Quarterly) }\end{array}$ & EGARCH & FB \\
\hline
\end{tabular}


International Journal of Social Science and Economic Research

ISSN: $2455-8834$

Volume: 05, Issue: 02 "February 2020"

\begin{tabular}{|l|l|l|l|l|l|}
\hline 25 & $\begin{array}{l}\text { Asghar et al } \\
(2011)\end{array}$ & $\begin{array}{l}\text { Pakistan, } \\
\text { India and } \\
\text { Sri Lanka }\end{array}$ & $\begin{array}{l}\text { 1980-2009 } \\
\text { (Quarterly) }\end{array}$ & EGARCH & $\begin{array}{l}\text { FB } \\
\text { CM }\end{array}$ \\
\hline 26 & $\begin{array}{l}\text { Karahan } \\
(2012)\end{array}$ & Turkey & $\begin{array}{l}2002-2011 \\
\text { (monthly) }\end{array}$ & ARMA-GARCH & FB \\
\hline 27 & $\begin{array}{l}\text { Balaji B. et al } \\
(2016)\end{array}$ & India & $\begin{array}{l}1961-2011 \\
\text { (monthly) }\end{array}$ & GARCH & FB \\
\hline * the hypothesis that had been supported & H \\
\hline
\end{tabular}

FB: Friedman-Ball hypothesis

CM: Cukierman -Meltzer Hypothesis

PM: Pourgerami -Maskus Hypothesis

H: Holland Hypothesis

Accordingly; out of 18 studies for HDCs, 13 studies support Friedman-Ball hypothesis, 10 support Cukierman -Meltzer Hypothesi, 2 support Holland Hypothesis, and none support Pourgerami -Maskus Hypothesis, and out of 27 studies for LDCs, 25 studies support FriedmanBall hypothesis, 9 support Cukierman -Meltzer Hypothesi, one supports Holland Hypothesis, and 2 support Pourgerami -Maskus Hypothesis.

\section{DATA AND RESEARCH METHODOLOGY:}

\subsection{Data:}

The variables used in this study are inflation (as a percentage change in consumer price index) and inflation uncertainty (as the conditional variance of GARCH model family). The data of inflation on monthly basis has been utilized from 2011:01-2018:11; and on annually basis from 1976-2016 ${ }^{1}$. The inflation data obtained from the official website of central bank of Egypt.

The study has applied some descriptive statistics (include Mean, Median, Standard deviation, Skewness, Kurtosis and Jarque-Bera test) to the inflation series. These descriptive statistics are mostly used to describe the basic structures of the data in the study. Accordingly; The summary statistics of the inflation rate time series presented in Table 2 in the statistical appendix shows 
that the inflation rate time series follows normal distribution with statistically significant (at 5\%) Jarque-Bera statistic .

The analysis begins with the examination of the inflation time series stationary using the Augmented Dickey Fuller (ADF) unit root test, which based on the null hypothesis that the time series are difference stationary using by the following three equations:

Without intercept and trend

$$
\Delta \pi_{\mathrm{t}}=\alpha \pi_{\mathrm{t}-1}+\sum_{\mathrm{i}=1}^{\mathrm{k}} \beta_{\mathrm{i}} \Delta \pi_{\mathrm{t}-\mathrm{i}}+\mathrm{e}_{\mathrm{t}}
$$

With intercept

$$
\Delta \pi_{\mathrm{t}}=\mathrm{C}+\alpha \pi_{\mathrm{t}-1}+\sum_{\mathrm{i}=1}^{\mathrm{k}} \beta_{\mathrm{i}} \Delta \pi_{\mathrm{t}-\mathrm{i}}+\mathrm{e}_{\mathrm{t}}-------(2)
$$

With intercept and trend

$$
\Delta \pi_{\mathrm{t}}=\mathrm{C}+\alpha \pi_{\mathrm{t}-1}+\sum_{\mathrm{i}=1}^{\mathrm{k}} \beta_{\mathrm{i}} \Delta \pi_{\mathrm{t}-\mathrm{i}}+\gamma_{t}+\mathrm{e}_{\mathrm{t}}
$$

Results of the ADF test have been presented in Table 3. All tests reject the null hypothesis of a unit root in the monthly inflation series at the $1 \%$ significance level. In other words; this means that the monthly inflation time series is integrated of zero order $\mathrm{I}(0)$.

\subsection{Inflation Uncertainty Framework}

To model inflation uncertainty different techniques have been applied for data analysis and for modeling purposes. So, the study has used GARCH, TARCH, EGARCH, and PARCH techniques to model the conditional variance which used as a proxy to inflation uncertainty.

The mean equation is

$$
\pi_{t}=\bar{\pi}+e_{t}
$$

Where $\bar{\pi}$ is the average value of inflation, so $e_{t}$ is the deviation of its mean at the time $t$.

Breusch-Godfrey serial correlation LM test shows that there is no serial correlation in the residuals. In particular, the test statistics is statistically significant at $1 \%$. 
1. The basic $\operatorname{GARCH}(1,1)$ conditional variance equation is given by the following equation (5):

$$
\delta_{t}^{2}=C+\alpha \cdot e_{t-1}^{2}+\beta \cdot \delta_{t-1}^{2}
$$

Where $\mathrm{c}$ is the constant term, $\mathrm{e}_{\mathrm{t}-1}^{2}$ (the $\mathrm{ARCH}$ term) is the first lag of the squared residual from the mean equation and expresses news about the volatility from the previous period, and term $\delta^{2} \mathrm{t}$ 1 (the GARCH term) represents last period's conditional variance. The specification of this model is consistent with the volatility that frequently seen in time series data, where large fluctuations are likely to be followed by large fluctuations and small fluctuations are likely to be followed by small fluctuations.

2. The TARCH $(1,1)$ specification for the conditional variance is:

$$
\delta_{t}^{2}=C+\alpha \cdot e_{t-1}^{2}+\beta \cdot \delta_{t-1}^{2}+\gamma \cdot e_{t-1}^{2} \cdot d_{t-1}
$$

The model is based on the assumption that unexpected change (expressed in terms of $e_{t}$ ), has different effect on the conditional variance. That is, the basic GARCH model is extended to include the term, where the dummy variable $\mathrm{d}_{t}=1$ if $\mathrm{e}_{\mathrm{t}}<0$, and 0 otherwise. In this model, If $\gamma>0$ indicates that volatility tends to rise in response to positive shocks and fall in response to negative shocks.

3. The Exponential GARCH (EGARCH) specifies the conditional variance in logarithmic form:

$$
\log \left(\delta_{t}^{2}\right)=C+\sum_{i=1}^{p} \alpha_{i} \cdot\left|\frac{e_{t-i}}{\delta_{t-1}}\right|+\sum_{j=1}^{q} \beta_{j} \cdot \log \left(\delta_{t-j}^{2}\right)+\sum_{k=1}^{r} \gamma_{k} \cdot \frac{e_{t-k}}{\delta_{t-k}}
$$

The form of the equation indicates that conditional variance is an exponential function of the variables under analysis, which implying that any effects are exponential (ensures that shocks will have a stronger impact on the volatility than in TARCH) and the conditional variance is positive.

4. The Power-ARCH (PARCH) represents a general class of models that include both ARCH and GARCH models, The PARCH specification is given by equation:

$$
\delta_{t}^{\sigma}=C+\sum_{i=1}^{p} \alpha_{i} \cdot\left(\left|e_{t-1}\right|-\gamma_{k} \cdot e_{t-i}\right)^{\sigma}\left|\frac{e_{t-i}}{\delta_{t-1}}\right|+\sum_{j=1}^{q} \beta_{j} \cdot \delta_{t-j}^{\sigma}
$$


Both the power parameter $\sigma$ and the threshold parameter, $\gamma$, are predetermined, so, some models can be derived from this model For each value of $\sigma$, and $\gamma$.

\subsection{Granger Causality Test}

Granger Causality is the method that has been used in most of previous studies to test the causality between Inflation $(\pi)$ and Inflation uncertainty $(\delta)$. The Granger causality test determines whether one variable is suitable in estimating the other or not. The bivariate regression function is as follows:

$$
\begin{gathered}
\pi_{t}=\alpha_{0}+\sum_{i=1}^{k} \alpha_{i} \pi_{t-i}+\sum_{j=1}^{m} \alpha_{j} \delta_{t-j}+\varepsilon_{t}-{ }^{----(9)} \\
\delta_{t}=\beta_{0}+\sum_{i=1}^{k} \beta_{i} \delta_{t-i}+\sum_{j=1}^{m} \beta_{j} \pi_{t-j}+\varepsilon_{t} \text {------(10) }
\end{gathered}
$$

Where denotes the constant term in the Granger regression, m represents the lag length chosen. The null hypothesis in the first equation is that inflation uncertainty does not granger cause inflation. Similarly the null hypothesis in the second equation is that inflation does not granger cause inflation uncertainty.

Results of the Granger causality test between Inflation $(\pi)$ and Inflation uncertainty $(\delta)$ obtained from GARCH, TARCH, EGARCH, and PARCH models presented in the following table:

Table 3: Causality test between inflation and inflation uncertainty

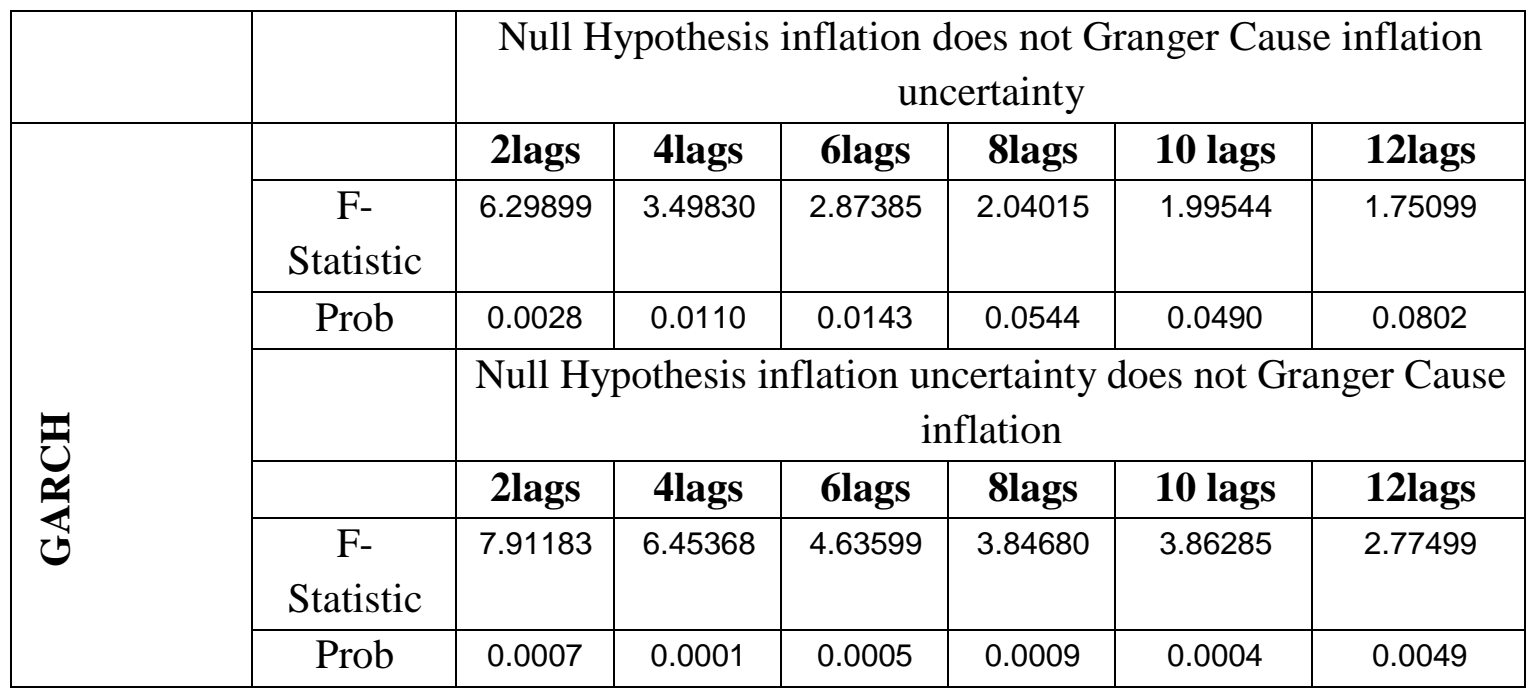


International Journal of Social Science and Economic Research

ISSN: $2455-8834$

Volume: 05, Issue: 02 "February 2020"

\begin{tabular}{|c|c|c|c|c|c|c|c|}
\hline \multirow{8}{*}{ 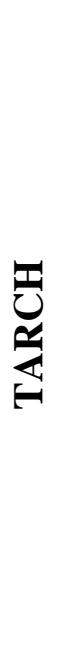 } & & \multicolumn{6}{|c|}{$\begin{array}{l}\text { Null Hypothesis inflation does not Granger Cause inflation } \\
\text { uncertainty }\end{array}$} \\
\hline & & 2lags & 4lags & 6lags & 8lags & 10 lags & 12lags \\
\hline & $\begin{array}{c}\text { F- } \\
\text { Statistic }\end{array}$ & 1.56662 & 1.19221 & 1.34732 & 1.05794 & 1.20883 & 1.07985 \\
\hline & Prob & 0.2146 & 0.3207 & 0.2473 & 0.4027 & 0.3032 & 0.3943 \\
\hline & & \multicolumn{6}{|c|}{$\begin{array}{l}\text { Null Hypothesis inflation uncertainty does not Granger Cause } \\
\text { inflation }\end{array}$} \\
\hline & & 2lags & 4lags & 6lags & 8lags & 10 lags & 12lags \\
\hline & $\begin{array}{c}\text { F- } \\
\text { Statistic }\end{array}$ & 6.40472 & 5.68594 & 4.27850 & 3.65046 & 3.65411 & 2.60814 \\
\hline & Prob & 0.0026 & 0.0004 & 0.0009 & 0.0014 & 0.0007 & 0.0078 \\
\hline \multirow{7}{*}{ لِّ } & & \multicolumn{6}{|c|}{$\begin{array}{l}\text { Null Hypothesis inflation does not Granger Cause inflation } \\
\text { uncertainty }\end{array}$} \\
\hline & & 2lags & 4lags & 6lags & 8lags & 10 lags & 12lags \\
\hline & $\begin{array}{c}\text { F- } \\
\text { Statistic }\end{array}$ & 2.77953 & 2.90597 & 2.25622 & 1.71898 & 1.87198 & 1.33314 \\
\hline & Prob & 0.0677 & 0.0267 & 0.0470 & 0.1097 & 0.0665 & 0.2266 \\
\hline & & \multicolumn{6}{|c|}{$\begin{array}{l}\text { Null Hypothesis inflation uncertainty does not Granger Cause } \\
\text { inflation }\end{array}$} \\
\hline & & 2lags & 4lags & 6lags & 8lags & 10 lags & 12lags \\
\hline & $\begin{array}{c}\text { F- } \\
\text { Statistic }\end{array}$ & 0.83156 & 0.79046 & 0.83402 & 0.84810 & 0.93409 & 0.81620 \\
\hline & Prob & 0.4388 & 0.5348 & 0.5475 & 0.5642 & 0.5088 & 0.6330 \\
\hline \multirow{8}{*}{ 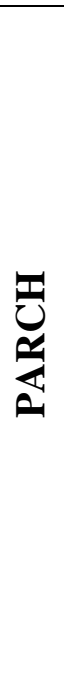 } & & \multicolumn{6}{|c|}{$\begin{array}{l}\text { Null Hypothesis inflation does not Granger Cause inflation } \\
\text { uncertainty }\end{array}$} \\
\hline & & 2lags & 4lags & 6lags & 8lags & 10 lags & 12lags \\
\hline & $\begin{array}{c}\text { F- } \\
\text { Statistic }\end{array}$ & 10.6560 & 7.35862 & 5.02268 & 4.01069 & 3.97955 & 2.93662 \\
\hline & Prob & 7.E-05 & 4.E-05 & 0.0002 & 0.0006 & 0.0003 & 0.0032 \\
\hline & & \multicolumn{6}{|c|}{$\begin{array}{c}\text { Null Hypothesis inflation uncertainty does not Granger Cause } \\
\text { inflation }\end{array}$} \\
\hline & & 2lags & 4lags & 6lags & 8lags & 10 lags & 12lags \\
\hline & $\begin{array}{c}\text { F- } \\
\text { Statistic }\end{array}$ & 54.2860 & 27.3636 & 18.5946 & 11.8627 & 9.35199 & 7.30655 \\
\hline & Prob & $6 . E-16$ & 3.E-14 & $5 . E-13$ & $2 . E-10$ & 3.E-09 & 8.E-08 \\
\hline
\end{tabular}




\section{International Journal of Social Science and Economic Research}

ISSN: $2455-8834$

Volume: 05, Issue: 02 "February 2020"

The table shows a bi-directional causality between inflation and inflation uncertainty. In particular, the Granger-causality test rejects the null hypothesis that inflation does not Grangercause inflation uncertainty across all lag lengths at the $1 \%$ level of significance. At the same time, the null hypothesis that inflation uncertainty does not Granger-cause inflation is also rejected for all the used lag lengths at one percent level of significance.

\section{CONCLUSIONS}

This paper has studied the association between inflation rate and inflation uncertainty in Egypt during the period January 2011-December 2018. Using two-step procedure, the estimated conditional variance from GARCH, TARCH, EGARCH and PARCH models are used as a measure of inflation uncertainty, and a Granger-causality test is accompanied to determine the causal relation between the two variables.

Results of the Granger causality test between Inflation and Inflation uncertainty obtained from GARCH family models show a bi-directional causality between inflation rate and inflation uncertainty.

But according to the coefficient of the error term (e) in the examined GARCH family models; it could be simply noticed that there is a significant positive association between inflation uncertainty and the error term (e), so where the error term represents the difference between inflation rate and the mean of inflation rate. It could be simply concluded that:

1. Inflation uncertainty is negatively associated with the mean of inflation rate, that is the more the mean of inflation rate, the less the inflation uncertainty at any high inflation rate.

2. Inflation uncertainty is positively associated with the inflation rate, in other words, the more the inflation rate, the more the inflation uncertainty at any high mean of inflation rate.

So, the results indicate a statistically significant positive, two-way relationship between higher (not high) inflation rate and inflation uncertainty, that is, higher inflation rate above its mean rate will lead to high inflation uncertainty and vice versa, and in the same time stable high inflation rate leads to less sensitiveness of inflation uncertainty to increase in inflation rate. In some context this result modifies both Friedman-Ball hypothesis and Cukierman and Meltzer Hypothesis that higher (not high) inflation rate affect and affected by inflation uncertainty. That is, according to the previous analyzes, one can simply conclude the following scenarios: 


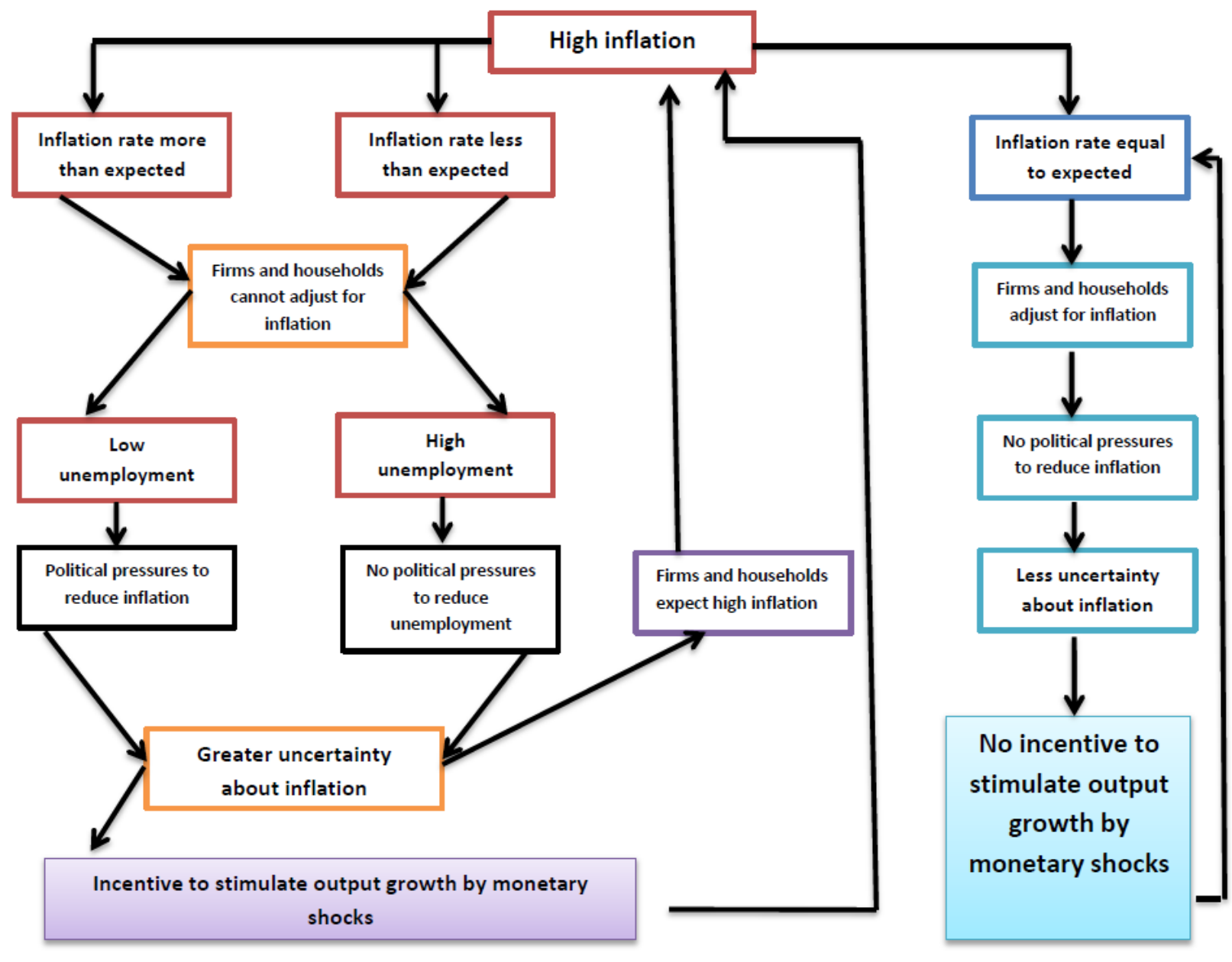

1. If inflation rate is more than expected, then firms and households cannot adjust for inflation, and unemployment rate will decrease, so there will be a political pressures to reduce high rate of inflation, hence the uncertainty about future inflation will increase, if this is the case, government may use monetary shocks to stimulate economic growth.

2. If inflation rate is less than expected, then firms and households cannot adjust for inflation, and unemployment rate will increase, so there will be a political pressures to reduce high rate of unemployment, hence the uncertainty about future inflation will increase, if this is the case, firms and households will expect high rate of inflation in the future which in turn promote for high inflation rate.

3. If inflation rate is equal to the expected, then firms and households can adjust for inflation, so there will not be a political pressures to reduce inflation even though if it is high, hence the uncertainty about future inflation will decrease, if this is the case, 


\section{International Journal of Social Science and Economic Research}

ISSN: $2455-8834$

Volume: 05, Issue: 02 "February 2020"

government haven't any incentive to use monetary shocks to stimulate economic growth and lose with economic stability.

\section{Policy Implications}

The bi-directional causality between inflation rate and inflation uncertainty that is found in this study has a vital implications for the monetary policy in Egypt. If the monetary policy attempt to control inflation uncertainty, then it should control the volatility of inflation rate (at any level of inflation itself), so it can stabilize inflation expectation and hence lower the inertia of inflation rates.

Where there is a considerable cost of inflation and inflation uncertainty especially when they have a mutual interdependence, the findings of this paper support the view of implementing inflation control target monetary policy in Egypt. Several studies (such as Tas and Ertugrul (2013) and Lin and Ye (2009)) have found that inflation targeting monetary policies have contributed to reduce both the level of inflation and its associated uncertainty.

\section{REFERENCES}

1. Ajevskis, V. 2007, Inflation and Inflation Uncertainty in Latvia, Bank of Latvia, (Working Paper No. 4/2007.)

2. Asghar, A., Ahmad, K., Ullah, S., Zaman, B., \& Rashid, M. T. (2011). The relationship between inflation and inflation uncertainty: a case study for SAARC region countries. International Research Journal of Finance and Economics, 66, 85-98.

3. Balaji, B., Durai, S. R. S., \& Ramachandran, M. (2016). The dynamics between inflation and inflation uncertainty: Evidence from india. Journal of Quantitative Economics, 14(1), $1-14$.

4. Ball, L. P., 1992. "Why Does High Inflation Raise Inflation Uncertainty?" Journal of Monetary Economics”, 29, p. 371-388.

5. Barnett, W., Ftiti, Z., \& Jawadi, F. (2018). The Causal Relationships between Inflation and Inflation Uncertainty. Available at: https://scholar.google.com/scholar?hl=en\&as_sdt=0\%2C5\&q=The+Causal+Relationshi ps+between+Inflation+and+Inflation+Uncertainty $+\& b t n G=$

6. Berument, H., Ozcan, K. M. \& Neyapt1, B. (2001). Modelling inflation uncertainty using EGARCH: An application to Turkey. Working Paper. Bilkent University.

7. Bhar, R. \& Mallik, G. (2010). Inflation, inflation uncertainty and output growth in the USA. Physica A: Statistical Mechanics and Its Applications, 389 (23), 5503-5510.

8. Bhar, R. and Hamori, S. 2001, "The Link between Inflation and Inflation Uncertainty: Evidence from G7 Countries", Empirical Economics 29. 
International Journal of Social Science and Economic Research

ISSN: $2455-8834$

Volume: 05, Issue: 02 "February 2020"

9. Bredin, D. and Fountas, S. 2006, "Inflation, Inflation Uncertainty, and Markov Regime Switching Heteroskedasticity: Evidence from European Countries", Money Macro and Finance (MMF) Research Group Conference 125.

10. Caporale, G.M., Onorante, L. \& Paesani, P. (2009). Inflation and inflation uncertainty in the Euro Area. CESifo Working Paper Series, 2720.

11. Chan, S. W. and Xie, Zixiong 2003, "Non-Linear Relationship Between Inflation and Inflation Uncertainty in Taiwan”, Applied Economic letter, 13, 529-533.

12. Condrad, C., Karanasos, M., 2005, "On the Inflation -Uncertainty Hypothesis in the USA, Japan, and the UK: A Dual Long Memory Approach”, Japan and World Economy, 17, p. 327-343.

13. Cuikerman A., Meltzer A., 1986, "A theory of Ambiguity, Credibility and Inflation under Discretion and Asymmetric Information”, Econometrica, 54, p. 1099-1128.

14. Davis, G. K., Kanago, B. E., 2000, "The Level and Uncertainty of Inflation; results from OECD Forecast”, Economic Inquiry, 38, p. 58-72.

15. Erdem, H. F., \& Yamak, R. (2016). Measuring the optimal macroeconomic uncertainty index for Turkey. Economic Annals, 61(210), 7-22.

16. Erdoğan, S. \& Bozkurt, H. (2004). Turkiye'de 1983-2003 doneminde enflasyon ile enflasyon belirsizliği ilişkisi. İktisat İsletme ve Finans, 19(8), 71-79. (In Turkish in Erdem, H. F., \& Yamak, R. (2016). Measuring the optimal macroeconomic uncertainty index for Turkey. Economic Annals, 61(210), 7-22.)

17. Erkam, S. (2008). Inflation and inflation uncertainty in Turkey, Sosyo-Ekonomi, 4(7), 157174. (In Turkish in Erdem, H. F., \& Yamak, R. (2016). Measuring the optimal macroeconomic uncertainty index for Turkey. Economic Annals, 61(210), 7-22.

18. Evans, M., Wachtel, P. 1993. Inflation regimes and the sources of inflation uncertainty. J.Money Credit Bank. 25, 475-511.

19. Fountas S., 2001, "The Relationship between Inflation and Inflation Uncertainty in the UK; 1885-1998”, Economics Letters, 74, p. 77-83.

20. Fountas S., 2010, "Inflation, Inflation Uncertainty and Growth: Are They Related", Economic Modeling, 27, p. 869-899.

21. Fountas S., Ioannidis, A., Karanasos, M., 2004, "Inflation, Inflation Uncertainty and a Common European Monetary Policy” Manchester School, 72, p. 221-242.

22. Fountas, S., Karanasos. M., 2007, "Inflation, Output Growth, and Nominal and Real Uncertainty: Empirical Evidence for the G7”, Journal of International Money and Finance, 26 (2007), p. 229-250.

23. Friedman, M., 1977, "Nobel Lecture: Inflation and Unemployment", Journal of Political Economy, 85, p. 451-472.

24. Golub, J., 1994. Does inflation uncertainty increases with inflation. Federal Reserve 
International Journal of Social Science and Economic Research

ISSN: $2455-8834$

Volume: 05, Issue: 02 "February 2020"

Bank of Kansas City. Third Quarter, 28-38.

25. Grier K. B., Grier, R., 2006, "On the Real Effects of Inflation on Inflation Uncertainty in Mexico“, Journal of Development Economics, 80, p. 478-500.

26. Grier K. B., Perry M. J., 1998, “On the Inflation and Inflation Uncertainty in the G-7 Countries", Journal of International Money and Finance, 17, p. 671-689.

27. Grier, K.B., Perry, M.J., 1998. On inflation and inflation uncertainty in the G7 countries. J.International Money and Finance. 17, 671- 689.

28. Holland, A. S., 1995, "Inflation and Uncertainty: Test for Temporal Ordering”, Journal of Money, Credit and Banking, 27, p.827-837.

29. Hwang, Y., 2001, "Relationship between Inflation and Rate and Inflation Uncertainty", Economic Letters, 173, p.179-186.

30. Jiranyakul, K. \& Opiela, T.P. (2010). Inflation and inflation uncertainty in the ASEAN-5 economies. Journal of Asian Economics, 21, 105-112.

31. Karahan, Ö. (2012). The relationship between inflation and inflation uncertainty: evidence from the Turkish economy. Procedia Economics and Finance, 1, 219-228.

32. Karanasos, M. \& Schurer, S. (2008). Is the relationship between inflation and its uncertainty linear? German Economic Review, 9(3), 265-286.

33. Keksek, S., Orhan, M., 2008, "Inflation and Inflation Uncertainty in Turkey", Applied Economics, 42: 10, p. 1281-1291.

34. Kontonikas, A., 2005. Inflation and inflation uncertainty in the United Kingdom, evidence from GARCH modelling, Economic Modelling. 21, 525-543.

35. Korap, L. \& Saatcioğlu, C. (2009). New time series evidence for the causality relationship between inflation and inflation uncertainty in the Turkish Economy. MPRA, 10(2), 235248.

36. Logue, D., Willett, T., 1976. A note on the relation between the rate and variability of inflation. Economica. 43, pp. 151-158.

37. Moradi, M. A. 2008, “A GARCH Model of Inflation and Inflation Uncertainty in Iran", Journal of Economic Research, 6.

38. Nas, T. F. and Perry, M. J. 2000, "Inflation, Inflation Uncertainty, and Monetary Policy in Turkey: 1960-1998”, Contemporary Economic Policy 18, 170-80.

39. Nas, T. F., J. Perry., 2000, "Inflation, Inflation Uncertainty and Monetary Policy in Turkey: 1960-1998”, Contemporary Economic Policy, 18, 2, p. 170-180.

40. Nazar D., Farshid, P. and Mojtaba, K. Z. M. 2010, "Asymmetry Effects of Inflation on Inflation Uncertainty in Iran: Using from EGARCH Model, 1959-2009”, American Journal of Applied Sciences, 7, 535-539.

41. Neanidis, C. K., Savva, S. C., 2011, "Nominal Uncertainty and Inflation: The role of European Union Membership”, Economic Letters, 112, p. 26-30. 


\section{International Journal of Social Science and Economic Research}

ISSN: $2455-8834$

Volume: 05, Issue: 02 "February 2020"

42. Okun, A., 1971, “The Mirage of Steady Inflation” Brooking Papers on Economic Activity, 2, p. 485-498.

43. Omay, T. (2008). The relationship between inflation, growth, nominal uncertainty and real uncertainty: The case of Turkey. Journal of Arts and Sciences, 10. (In Turkish Erdem, H. F., \& Yamak, R. (2016). Measuring the optimal macroeconomic uncertainty index for Turkey. Economic Annals, 61(210), 7-22.)

44. Ozdemir, Z. A. \& Fisunoğlu, M. (2008). On the inflation-uncertainty hypothesis in Jordan, Philippines and Turkey: A Long Memory Approach. International Review of Economics and Finance, 17, 1- 12.

45. Ozer, M. \& Turkyılmaz, S. (2005). Turkiye'de enflasyon ile enflasyon belirsizliği arasındaki ilişkinin zaman serisi analizi. İktisat Işletme ve Finans, 2005(5), 93-104. (In Turkish in Erdem, H. F., \& Yamak, R. (2016). Measuring the optimal macroeconomic uncertainty index for Turkey. Economic Annals, 61(210), 7-22.)

46. Perry, M. and Grier, K. B. 1998, "On Inflation and Inflation Uncertainty in the G-7 Countries", Journal of International Money and Finance, 17, 671-689.

47. Pourgerami, A., Maskus, K., 1987, “The Effects of Inflation on the Predictability of Price Changes in Latin America: Some Estimates and Policy Implications", World Development, 15, 1, p. 287-290.

48. Rizvi, K. A. and Naqvi B. 2008, "Asymmetric Behavior of Inflation Uncertainty and Friedman- Ball Hypothesis: Evidence from Pakistan”, The Lahore Journal of Economics, 15: 2, pp. 1-33.

49. Rizvi., K. A. and Naqvi, B. 2009, "Inflation Volatility: An Asian Perspective", University Library of Munich, Germany, (MPRA paper No. 19489.)

50. Rossi, B., Sekhposyan, T. and Soupre, M. 2016. "Understanding the Sources of Macroeconomic Uncertainty," Working Papers 920, Barcelona Graduate School of Economics.

51. Rossi, B., Sekhposyan, T., \& Soupre, M. (2016). Understanding the sources of macroeconomic uncertainty. Working Papers 920, Barcelona Graduate School of Economics. Available at:

https://scholar.google.com/scholar?hl=en\&as_sdt=0\%2C5\&q=Under standing+the+Sources+of+Macroeconomic+Uncertainty\%2C\&btnG=.

52. Telatar, F. (2003). Turkiye'de enflasyon, enflasyon belirsizliği ve siyasi belirsizlik arasındaki nedensellik ilişkileri. İktisat Isşletme ve Finans, 2003(2), 43-51. (In Turkish in Erdem, H. F., \& Yamak, R. (2016). Measuring the optimal macroeconomic uncertainty index for Turkey. Economic Annals, 61(210), 7-22.)

53. Teletar, F., Teletar, E., 2003, "The Relationship between Inflation and Different Sources of Inflation Uncertainty in Turkey", Applied Economics Letters, 10, 7, p. 431-435. 
54. Thornton, J. 2006, "Inflation and Inflation Uncertainty in India, 1957-2005", Indian Economic Review, 41, 1-8.

55. Thorton J., 2007, "The Relationship between Inflation and Inflation Uncertainty in Emerging Market Economies”, Southern Economic Journal, 73, 4, 858-870.

56. Thorton J., 2008, "Inflation and Inflation Uncertainty in Argentina, 1810-2005", Economic Letters, 98, p.247-252.

57. Turkyllmaz, S. \& Ozer, M. (2009). MGARCH modelling of the relationship among inflation, output, nominal and real uncertainty in Turkey", MIBES Transactions, 4(1), 125137.

58. Ungar, M., Zilberfarb, B., (1993) "Inflation and Its Unpredictability- Theory and Empirical Evidence”, Journal of Money, Credit and Banking, 25, p. 709-720.

59. Wilson, B. K., 2006, "The Links between Inflation, Inflation Uncertainty and Output Growth New Time Series Evidence from Japan”, Journal of Macroeconomics, 28, p. 206220.

60. Yamak, R. (1996). Inflation and inflation uncertainty in Turkey. İsletme ve Finans, 121(11), 37-46. (In Turkish in Erdem, H. F., \& Yamak, R. (2016). Measuring the optimal macroeconomic uncertainty index for Turkey. Economic Annals, 61(210), 7-22.)

\section{STATISTICAL APPENDIX}

\section{Summary of statistics}

\begin{tabular}{lcc}
\hline & Monthly; & Annually; \\
\hline Mean & & \\
Median & 0.010641 & 11.46708 \\
Maximum & 0.010010 & 11.07810 \\
Minimum & 0.048500 & 23.86429 \\
Std. Dev. & -0.015350 & 2.269757 \\
Skewness & 0.011391 & 5.629899 \\
Kurtosis & 0.564124 & 0.216911 \\
Jarque-Bera & 3.937336 & 2.317422 \\
Probability & 8.337233 & 1.117445 \\
Sum & 0.015474 & 0.571939 \\
Sum Sq. Dev. & 0.989640 & 470.1504 \\
Observations & 0.011937 & 1267.830 \\
\hline
\end{tabular}


International Journal of Social Science and Economic Research

ISSN: 2455-8834

Volume: 05, Issue: 02 "February 2020"

\section{Unit root test;}

\begin{tabular}{|c|c|c|c|c|c|c|}
\hline \multicolumn{6}{|c|}{ Augmented Dickey-Fuller test statistic } \\
\hline & \multicolumn{3}{|c|}{ Monthly } & \multicolumn{3}{c|}{ Annually } \\
\hline & Intercept & $\begin{array}{c}\text { Intercept } \\
\text { \& trend }\end{array}$ & none & Intercept & $\begin{array}{c}\text { Intercept } \\
\text { \& trend }\end{array}$ & none \\
\hline t-Statistic & -6.657809 & -7.138874 & -4.45787 & -1.690101 & -1.840943 & -0.64238 \\
\hline prob & 0.0000 & 0.0000 & 0.0000 & 0.4282 & 0.6654 & 0.4325 \\
\hline
\end{tabular}

\section{Estimation of inflation uncertainty:}

\section{Mean equation}

Dependent Variable: INF

Method: Least Squares

Sample (adjusted): 2011M01 2018M09

\begin{tabular}{lcllr}
\hline \multicolumn{1}{c}{ Variable } & Coefficient & \multicolumn{1}{c}{ Std. Error } & t-Statistic & \multicolumn{1}{c}{ Prob. } \\
\hline \multicolumn{1}{c}{ C } & 0.010641 & 0.001181 & 9.008998 & 0.0000 \\
\hline R-squared & 0.000000 & Mean dependent var & 0.010641 \\
Adjusted R-squared & 0.000000 & S.D. dependent var & 0.011391 \\
S.E. of regression & 0.011391 & Akaike info criterion & -6.101303 \\
Sum squared resid & 0.011937 & Schwarz criterion & -6.074071 \\
Log likelihood & 284.7106 & Hannan-Quinn criter. & -6.090308 & \\
Durbin-Watson & 1.338853 & & & \\
stat & & & & \\
\hline
\end{tabular}


International Journal of Social Science and Economic Research

ISSN: $2455-8834$

Volume: 05, Issue: 02 "February 2020"
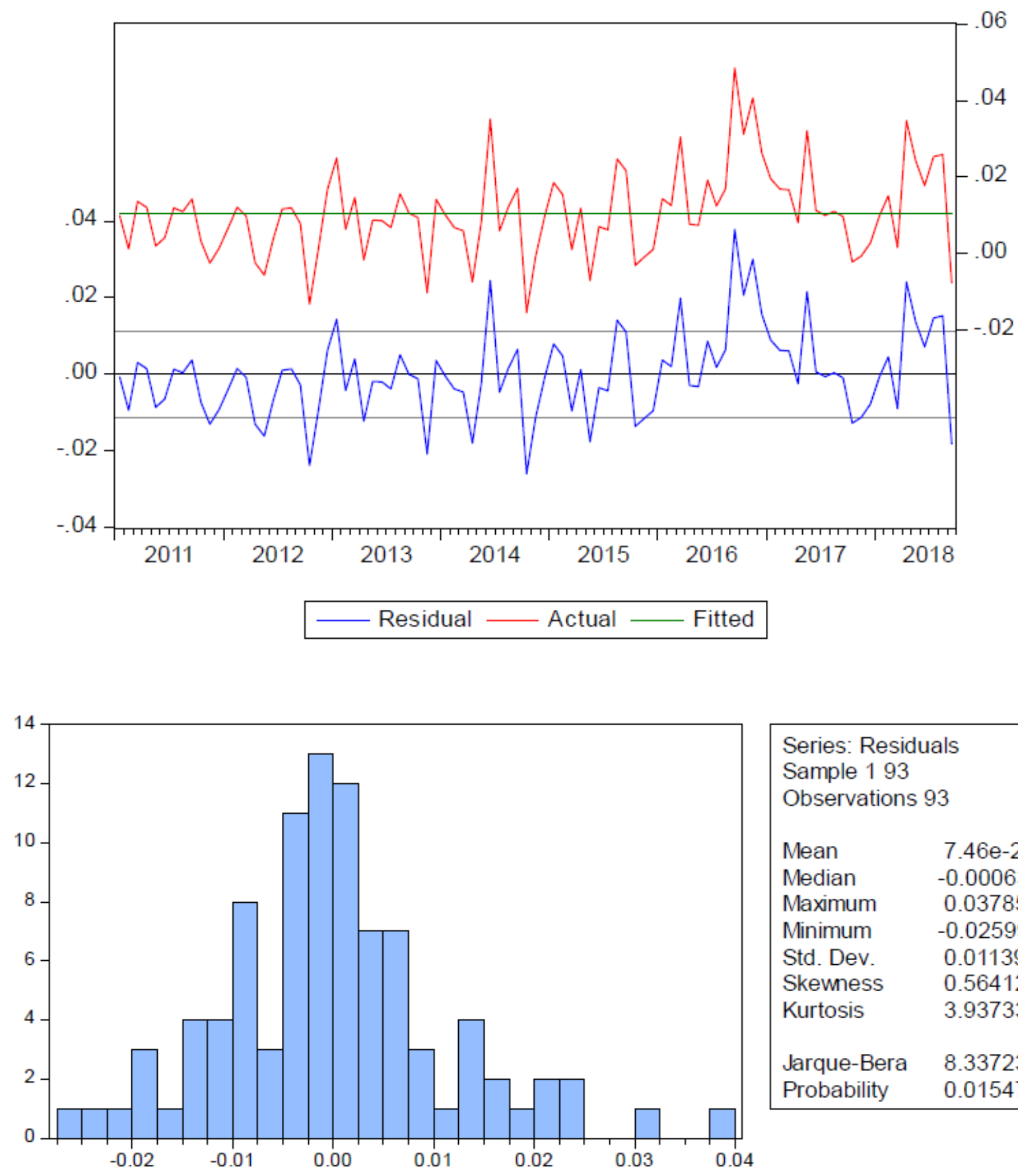

Series: Residuals

Sample 193

Observations 93

Mean

$7.46 \mathrm{e}-20$

Median

$-0.000631$

Maximum

0.037859

Minimum

$-0.025991$

Std. Dev.

0.011391

Skemess

0.564124

Kurtosis

3.937336

Jarque-Bera

8.337233

Probability

0.015474

Breusch-Godfrey Serial Correlation LM Test:

\begin{tabular}{llll}
\hline F-statistic & 5.219224 & Prob. F(2,90) & 0.0072 \\
Obs*R-squared & 9.665378 & Prob. Chi-Square(2) & 0.0080 \\
\hline
\end{tabular}




\section{Estimation of GARCH model}

\begin{tabular}{|c|c|c|c|c|}
\hline $\begin{array}{l}\text { Dependent Variable: } \\
\text { Method: ML ARCH } \\
\text { Included observation } \\
\text { GARCH }=\mathrm{C}(2)+\mathrm{C}\end{array}$ & $\begin{array}{l}\text { distribution ( } \\
(-1)^{\wedge} 2+C(4\end{array}$ & $\begin{array}{l}\text { FGS / Marquar } \\
\text { *GARCH(-1) }\end{array}$ & eps) & \\
\hline Variable & Coefficient & Std. Error & z-Statistic & Prob. \\
\hline $\mathrm{C}$ & 0.009116 & 0.001254 & 7.267827 & 0.0000 \\
\hline \multicolumn{5}{|c|}{ Variance Equation } \\
\hline $\mathrm{C}$ & $1.51 \mathrm{E}-06$ & $1.02 \mathrm{E}-06$ & 1.484926 & 0.1376 \\
\hline $\operatorname{RESID}(-1)^{\wedge} 2$ & -0.084143 & 0.021332 & -3.944457 & 0.0001 \\
\hline GARCH(-1) & 1.093513 & 0.000262 & 4170.569 & 0.0000 \\
\hline R-squared & -0.018123 & \multicolumn{2}{|c|}{ Mean dependent var } & 0.010641 \\
\hline Adjusted R-squared & -0.018123 & \multicolumn{2}{|c|}{ S.D. dependent var } & 0.011391 \\
\hline S.E. of regression & 0.011494 & \multicolumn{2}{|c|}{ Akaike info criterion } & -6.266371 \\
\hline Sum squared resid & 0.012154 & \multicolumn{2}{|c|}{ Schwarz criterion } & -6.157442 \\
\hline Log likelihood & 295.3862 & \multicolumn{2}{|c|}{ Hannan-Quinn criter. } & -6.222388 \\
\hline Durbin-Watson stat & 1.315020 & & & \\
\hline
\end{tabular}

\section{Causality test:}

\begin{tabular}{|c|c|c|c|c|c|c|}
\hline & \multicolumn{7}{|c|}{ Null Hypothesis inflation does not Granger Cause inflation } \\
& uncertainty \\
\hline & 2lags & 4lags & 6lags & 8lags & 10 lags & 12lags \\
\hline F-Statistic & 6.29899 & 3.49830 & 2.87385 & 2.04015 & 1.99544 & 1.75099 \\
\hline Prob & 0.0028 & 0.0110 & 0.0143 & 0.0544 & 0.0490 & 0.0802 \\
\hline & Null Hypothesis inflation uncertainty does not Granger Cause \\
& \multicolumn{7}{|c|}{ inflation } \\
\hline & 2lags & 4lags & 6lags & 8lags & $\mathbf{1 0 ~ l a g s ~}$ & 12lags \\
\hline F-Statistic & 7.91183 & 6.45368 & 4.63599 & 3.84680 & 3.86285 & 2.77499 \\
\hline Prob & 0.0007 & 0.0001 & 0.0005 & 0.0009 & 0.0004 & 0.0049 \\
\hline
\end{tabular}




\section{Estimation of TARCH MODEL}

\begin{tabular}{|c|c|c|c|c|}
\hline \multicolumn{5}{|c|}{$\begin{array}{l}\text { Dependent Variable: INF } \\
\text { Method: ML ARCH - Normal distribution (BFGS / Marquardt steps) } \\
\text { Included observations: } 93 \\
\text { GARCH }=\mathrm{C}(2)+\mathrm{C}(3) * \operatorname{RESID}(-1)^{\wedge} 2+\mathrm{C}(4) * \operatorname{RESID}(-1)^{\wedge} 2 *(\operatorname{RESID}(-1)<0)+ \\
\qquad \mathrm{C}(5) * \mathrm{GARCH}(-1)\end{array}$} \\
\hline Variable & Coefficient & Std. Error & z-Statistic & Prob. \\
\hline $\mathrm{C}$ & 0.009134 & 0.001387 & 6.586075 & 0.0000 \\
\hline \multicolumn{5}{|c|}{ Variance Equation } \\
\hline $\mathrm{C}$ & $2.96 \mathrm{E}-06$ & $2.77 \mathrm{E}-06$ & 1.067455 & 0.2858 \\
\hline $\operatorname{RESID}(-1)^{\wedge} 2$ & -0.084077 & 0.026368 & -3.188592 & 0.0014 \\
\hline $\begin{array}{l}\operatorname{RESID}(- \\
1)^{\wedge} 2 *(\operatorname{RESID}(-1)<0)\end{array}$ & -0.043233 & 0.084429 & -0.512065 & 0.6086 \\
\hline GARCH(-1) & 1.093807 & 0.000236 & 4626.916 & 0.0000 \\
\hline R-squared & -0.017699 & \multicolumn{2}{|c|}{ Mean dependent var } & 0.010641 \\
\hline Adjusted R-squared & -0.017699 & \multicolumn{2}{|c|}{ S.D. dependent var } & 0.011391 \\
\hline S.E. of regression & 0.011491 & \multicolumn{2}{|c|}{ Akaike info criterion } & -6.239529 \\
\hline Sum squared resid & 0.012149 & \multicolumn{2}{|c|}{ Schwarz criterion } & -6.103368 \\
\hline Log likelihood & 295.1381 & \multirow{2}{*}{\multicolumn{2}{|c|}{ Hannan-Quinn criter. }} & -6.184551 \\
\hline Durbin-Watson stat & 1.315569 & & & \\
\hline
\end{tabular}

\section{Causality test:}

\begin{tabular}{|c|c|c|c|c|c|c|}
\hline & \multicolumn{6}{|c|}{ Null Hypothesis inflation does not Granger Cause inflation } \\
& 2lags & 4lags & 6lags & 8lags & 10 lags & 12lags \\
\hline & 1.56662 & 1.19221 & 1.34732 & 1.05794 & 1.20883 & 1.07985 \\
\hline F-Statistic & 0.2146 & 0.3207 & 0.2473 & 0.4027 & 0.3032 & 0.3943 \\
\hline Prob & Null Hypothesis inflation uncertainty does not Granger Cause \\
& \multicolumn{7}{|c|}{ inflation } \\
\hline & 2lags & 4lags & 6lags & 8lags & $\mathbf{1 0 ~ l a g s ~}$ & 12lags \\
\hline F-Statistic & 6.40472 & 5.68594 & 4.27850 & 3.65046 & 3.65411 & 2.60814 \\
\hline Prob & 0.0026 & 0.0004 & 0.0009 & 0.0014 & 0.0007 & 0.0078 \\
\hline
\end{tabular}




\section{Estimation of EGARCH model}

\begin{tabular}{|c|c|c|c|c|}
\hline $\begin{array}{l}\text { Dependent Variable: } \\
\text { Method: ML ARCH } \\
\text { Included observation } \\
\text { LOG(GARCH) }=\mathrm{C}( \\
\text { *RESID }(-1) / @\end{array}$ & $\begin{array}{l}\text { distribution ( } \\
\text { ABS(RESID } \\
\text { RCH(-1)) + }\end{array}$ & $\begin{array}{l}\text { FGS / Marquar } \\
-1) / @ S Q R T(G \\
\text { (5)*LOG(GAR }\end{array}$ & $\begin{array}{l}\text { eps) } \\
(-1)) \\
(-1)))+C\end{array}$ & \\
\hline Variable & Coefficient & Std. Error & z-Statistic & Prob. \\
\hline $\mathrm{C}$ & 0.008935 & 0.000815 & 10.96387 & 0.0000 \\
\hline \multicolumn{5}{|c|}{ Variance Equation } \\
\hline $\mathrm{C}(2)$ & -0.613756 & 0.001085 & -565.4219 & 0.0000 \\
\hline $\mathrm{C}(3)$ & -0.549083 & 0.013194 & -41.61689 & 0.0000 \\
\hline $\mathrm{C}(4)$ & 0.188157 & 0.037300 & 5.044363 & 0.0000 \\
\hline $\mathrm{C}(5)$ & 0.889286 & $1.8 \mathrm{E}-104$ & $4.9 \mathrm{E}+103$ & 0.0000 \\
\hline R-squared & -0.022671 & \multicolumn{2}{|c|}{ Mean dependent var } & 0.010641 \\
\hline Adjusted R-squared & -0.022671 & \multicolumn{2}{|c|}{ S.D. dependent var } & 0.011391 \\
\hline S.E. of regression & 0.011519 & \multicolumn{2}{|c|}{ Akaike info criterion } & -6.250468 \\
\hline Sum squared resid & 0.012208 & \multicolumn{2}{|c|}{ Schwarz criterion } & -6.114307 \\
\hline Log likelihood & 295.6468 & \multicolumn{2}{|c|}{ Hannan-Quinn criter. } & -6.195490 \\
\hline Durbin-Watson stat & 1.309172 & & & \\
\hline
\end{tabular}

\section{Causality test:}

\begin{tabular}{|c|c|c|c|c|c|c|}
\hline & \multicolumn{7}{|c|}{ Null Hypothesis inflation does not Granger Cause inflation } \\
& uncertainty \\
\hline & 2lags & 4lags & 6lags & 8lags & 10 lags & 12lags \\
\hline F-Statistic & 2.77953 & 2.90597 & 2.25622 & 1.71898 & 1.87198 & 1.33314 \\
\hline Prob & 0.0677 & 0.0267 & 0.0470 & 0.1097 & 0.0665 & 0.2266 \\
\hline & Null Hypothesis inflation uncertainty does not Granger Cause \\
& \multicolumn{7}{|c|}{ inflation } \\
\hline & 2lags & 4lags & 6lags & 8lags & $\mathbf{1 0 ~ l a g s ~}$ & 12lags \\
\hline F-Statistic & 0.83156 & 0.79046 & 0.83402 & 0.84810 & 0.93409 & 0.81620 \\
\hline Prob & 0.4388 & 0.5348 & 0.5475 & 0.5642 & 0.5088 & 0.6330 \\
\hline
\end{tabular}




\section{Estimation of PARCH MODEL:}

\begin{tabular}{|c|c|c|c|c|}
\hline \multicolumn{5}{|c|}{$\begin{array}{l}\text { Dependent Variable: INF } \\
\text { Method: ML ARCH - Normal distribution (BFGS / Marquardt steps) } \\
\text { Included observations: } 93 \\
\text { @ SQRT(GARCH)^C(6)= } \mathrm{C}(2)+\mathrm{C}(3)^{*}\left(\mathrm{ABS}(\operatorname{RESID}(-1))-\mathrm{C}(4)^{*} \mathrm{RESID}(\right. \\
\quad-1))^{\wedge} \mathrm{C}(6)+\mathrm{C}(5)^{*} @ \mathrm{SQRT}(\mathrm{GARCH}(-1))^{\wedge} \mathrm{C}(6)\end{array}$} \\
\hline Variable & Coefficient & Std. Error & z-Statistic & Prob. \\
\hline $\mathrm{C}$ & 0.008234 & 0.001222 & 6.739239 & 0.0000 \\
\hline \multicolumn{5}{|c|}{ Variance Equation } \\
\hline $\mathrm{C}(2)$ & $-1.15 \mathrm{E}-05$ & $1.66 \mathrm{E}-05$ & -0.691301 & 0.4894 \\
\hline $\mathrm{C}(3)$ & -0.054599 & 0.059566 & -0.916598 & 0.3594 \\
\hline $\mathrm{C}(4)$ & -0.817840 & 1.517865 & -0.538810 & 0.5900 \\
\hline $\mathrm{C}(5)$ & 1.090244 & 0.000248 & 4390.097 & 0.0000 \\
\hline$C(6)$ & 1.437166 & 0.010246 & 140.2603 & 0.0000 \\
\hline R-squared & -0.045152 & \multicolumn{2}{|c|}{ Mean dependent var } & 0.010641 \\
\hline Adjusted R-squared & -0.045152 & \multicolumn{2}{|c|}{ S.D. dependent var } & 0.011391 \\
\hline S.E. of regression & 0.011645 & \multicolumn{2}{|c|}{ Akaike info criterion } & -6.193056 \\
\hline Sum squared resid & 0.012476 & \multicolumn{2}{|c|}{ Schwarz criterion } & -6.029662 \\
\hline Log likelihood & 293.9771 & \multicolumn{2}{|c|}{ Hannan-Quinn criter. } & -6.127082 \\
\hline Durbin-Watson stat & 1.281012 & & & \\
\hline
\end{tabular}

\section{Causality test:}

\begin{tabular}{|c|c|c|c|c|c|c|}
\hline & \multicolumn{6}{|c|}{$\begin{array}{l}\text { Null Hypothesis inflation does not Granger Cause inflation } \\
\text { uncertainty }\end{array}$} \\
\hline & 2lags & 4lags & 6lags & 8lags & 10 lags & 12lags \\
\hline F-Statistic & 10.6560 & 7.35862 & 5.02268 & 4.01069 & 3.97955 & 2.93662 \\
\hline \multirow[t]{4}{*}{ Prob } & 7.E-05 & 4.E-05 & 0.0002 & 0.0006 & 0.0003 & 0.0032 \\
\hline & \multicolumn{6}{|c|}{ Null Hypothesis inflation uncertainty does not Granger Cause } \\
\hline & \multicolumn{6}{|c|}{ inflation } \\
\hline & 2lags & 4lags & 6lags & 8lags & 10 lags & 12lags \\
\hline F-Statistic & 54.2860 & 27.3636 & 18.5946 & 11.8627 & 9.35199 & 7.30655 \\
\hline Prob & 6.E-16 & 3.E-14 & 5.E-13 & $2 . E-10$ & 3.E-09 & 8.E-08 \\
\hline
\end{tabular}

